\title{
ANALYSIS OF THE DETERMINANTS OF PRODUCT COMPETITION AND WELFARE OF VIRGINIA TOBACCO AT EAST LOMBOK OF EAST NUSA TENGGARA PROVINCE, INDONESIA
}

\author{
Suparlan* \\ Postgraduatie Program, University of Udayana, Denpasar, Indonesia \\ Setiawina Djinar, Budhi Md Kembar Sri, Yasa Murjana, Lecturers \\ University of Udayana, Denpasar, Indonesia \\ *E-mail: suparlan.ugr@gmail.com
}

\begin{abstract}
This study examines whether the intensity of partnerships, entrepreneurial orientation, the role of government and social capital indirectly affect the welfare of farmers through Virginia tobacco competitiveness. Sampling technique used is Simple Random Sampling because the population of partner farmers has homogeneous characteristics. Each population has the same opportunity to be a respondent in this study from 84 partner farmers in Gelanggang Village and 68 partner farmers in Sukadana Village. The PLS evaluation model consists of three parts, namely the evaluation of the measurement model (outer model) more specifically about the relationship of indicator blocks or question items to variables, the evaluation of structural models (Inner models) that specifically connect between latent variables and hypothesis testing. SEM-PLS test results of the relationship between variables can be stated that the relationship between the intensity of partnerships with product competitiveness has no significant effect. The relationship between partnership intensity and farmers' welfare is not significant. The relationship between entrepreneurship orientation and product competitiveness is significant. The relationship between entrepreneurship orientation and farmers' welfare is significant. The relationship between the role of government and product competitiveness is not significant. The relationship between the role of government and farmers' welfare is significant. The relationship between social capital and product competitiveness is not significant. The relationship between social capital and farmers' welfare is not significant. The relationship of product competitiveness with the welfare of farmers has a positive and significant effect on the welfare of farmers. The relationship between partnership intensity and farmers' welfare through product competitiveness is not significant. The relationship between entrepreneurship orientation with farmers' welfare through product competitiveness has a direct and significant influence. The relationship between the role of government and farmers' welfare is not significant. The relationship between social capital and welfare through product competitiveness is not significant.
\end{abstract}

\section{KEY WORDS}

Intensity of partnerships, entrepreneurial orientation, role of government, social capital, product competitiveness, farmers' welfare.

Tobacco farmers carry out the production process well to produce high quality products. The price of tobacco products is determined by quality, farmers get income from quantity times price. Farmers' welfare is determined by tobacco farming income, but to determine welfare is indicated by the fulfillment of spiritual and material needs (Bappenas, 2008). The same thing was mentioned by (Grinols, 1994; Chapra, 2001), welfare is shown by the presence of harmony in harmonious family relationships, noble behavior and behavior based on spiritual values.

Virginia tobacco farmer income is determined by the quantity and quality of production which is influenced by weather factors, capital and selling prices. Nicholson (2002), mentions the condition of the price of goods and tastes of the community remains, then the increase in 
income shows the welfare of the community increases. Furthermore, objective forms of satisfaction and subjective happiness increase the quality of human life to show welfare improvement (Bronsteen et al., 2009). Farmers will be said to be in a condition of welfare if their income is able to meet material and non-material needs. National virginia tobacco products are unable to meet the needs of national cigarette raw materials so they import. Lombok virginia tobacco cultivated by farmers has long been known to have high quality that is able to compete with imported products (Surakhmad, 2002). The determinant of farmers' welfare is determined by the competitiveness of Virginia tobacco products. The pattern of virginia tobacco farming in Lombok with a pattern of partnership and self-help. The price determination is set by the partner company and the partner farmer aimed at benefiting both parties, some of the profits can be used to strengthen product competitiveness (Kotler and Armstrong, 2008).

The partnership pattern carried out by small-scale farmers can increase farmers' income through increased production (Bolwig et al., 2009). Commodity development requires a partnership pattern between farmers, the private sector, the government and academics (Kurniawan et al., 2011). Glover (1994), mentions farmers partnered to reduce production and marketing risks. Jackson and Cheater (1994); Artur (2005), the participation of farmers in partnerships can reduce production costs due to the use of new technologies accessed from partner companies, reduction of transportation costs and marketing costs.

The sustainability of partnerships is the hope of partner companies and partner farmers as well as the government. Parties who agree to a contract in partnership are voluntary based on the principle of mutual support and benefit, accompanied by coaching (Partomo and Soejoedono, 2002; Serad, 2006; Mardikanto, 2009; Martodireso and Suryanto cited by Prasticha, 2013). But what happened was that both partner companies and partner farmers violated contracts that disturbed the sustainability of the partnership. Hamidi (2001); Douma and Schreuder (1992: 59), said that even though companies and farmer partners had been formally bound by contracts, often there were still deviations. The existence of a black market that buys more expensive tobacco farmers has an impact on the price of tobacco in Lombok (Hamidi, 2007). The ability of farmers to see opportunities originating from an entrepreneurial orientation needs to be improved to improve product competitiveness.

Entrepreneurial orientation (entrepreneurial orientation) is related to psychometric aspects as seen from its innovation, proactive nature and courage to take risks. Farmers face uncertain conditions such as the amount of tobacco product purchases and prices set by the company each season. Lombok virginia tobacco farmers are expected to have an entrepreneurial spirit that is reflected in their ability to innovate and take risks. Farmers are not much entrepreneurial oriented because the factors that influence entrepreneurial behavior are the economic, social and political environment by (Mazzarol et al., 1999 and Kumar et al., 2003). Farmers who have an entrepreneurial orientation are able to reduce lower costs and increase productivity (Wirasasmita, 2011). Farmers can make efficiency so farmers can reduce production costs so that farmers 'profits are high and thus farmers' welfare is achieved. The entrepreneurial behavior can increase the success of small-scale agro industry (Dirlanudin, 2010).

The government has an interest in developing leading agricultural commodities, so it is necessary to optimize the use of government support and the use of information technology (Rahayu, 2011). An atmosphere of mutual support and benefit between partner companies, partner farmers and the government is needed, the government is expected to play its role as a coach and oversee the implementation of partners (Sjamsuddin, 2006). Farmers are often faced with the non-opening of partner companies in determining the grade of tobacco that determines prices. The government has an interest in maintaining the welfare of farmers, so companies are required to determine the price and the quota of products purchased earlier. Farmers are always in a weak condition or do not have a good bargaining position, when the production quantity exceeds the purchase quota prepared by the company, often the partner company argues that the farmers are over-production. Over production occurs when supply exceeds demand, as a result the price will go down then the law of demand applies. 
The strength of social capital is its ability to understand how individuals are able to move their networks to increase profits in their environment (Capello and Faggian, 2005; Malecki, 2012; Rutten et al., 2010; Westlund and Bolton, 2003). Mawardi (2007), states that social capital is a resource that can be seen as an investment to get new resources. The dimensions of social capital are broad, complex and are more than just social capital focused on the dimensions of power, expertise and managerial that each individual has. The formulation of the problem that will be answered in this study is as follows. 1) What is the effect of the intensity of partnership, entrepreneurial orientation, the role of government and social capital on virginia tobacco competitiveness in the East Lombok Regency of West Nusa Tenggara Province? 2) What is the effect of the intensity of partnership, entrepreneurial orientation, the role of government, social capital and competitiveness towards the welfare of virginia tobacco farmers in the area of East Lombok Regency, West Nusa Tenggara Province? 3) Does the intensity of the partnership, entrepreneurial orientation, the role of government and social capital indirectly affect the welfare of farmers through the competitiveness of virginia tobacco in the region of East Lombok Regency, West Nusa Tenggara Province?

\section{METHODS OF RESEARCH}

This research was conducted in East Lombok Regency by taking 9 districts out of 21 existing districts, in nine districts where virginia tobacco is cultivated, namely Terara, Sikur, Montong Gading, Sukamulia, Sakra, East Sakra, West Sakra, Keruak and Joruwaru Districts. Determination of research locations using the Multiple Stage Sampling method is a method of determining the location of research that is drawn in stages starting from the district level to the village level. The population in this study were all virginia tobacco partner farmers in Gelanggang Village, Sakra Timur District and Sukadana Village Terara District in East Lombok Regency. Procedure Determination of the sample or respondent in this study using a random method. The total population of 152 farmers is partnering with the details of the village of Sukadana totaling 68 farmers and Gelanggang village of 84 farmers. Determination of the number of samples of this study using the Slovin formula with a margin of error of 0.06 , obtained the number of respondents in this study of 99 farmers in partnership with the following calculations:

$$
n=\frac{N}{1+N e^{2}}=98,24
$$

Based on the calculation of the Slovin formula, the number 98.24 was rounded up to 99, so that the number of samples for this study were 99 partner farmers. Allocation of sample size to village representation was carried out proportionally according to the number of partner farmer populations in each village, carried out in the following manner.

Table 1 - Location of District, Village and Number of Population and Sample of Partner Farmers Becoming Respondents

\begin{tabular}{|c|c|c|c|}
\hline Subdistric & Village & Population Farmer Partners & Sample Farmer Partners \\
\hline Sakra Timur & Gelanggang & 84 & 55 \\
\hline Terara & Sukadana & 68 & 44 \\
\hline \multicolumn{2}{|c|}{ Total } & 152 & 99 \\
\hline
\end{tabular}

Source: Survey Results, 2019.

Sampling of research using Simple Random Sampling is used because the population of partner farmers has homogeneous characteristics. Each population has the same opportunity to become respondents in this study from 84 partner farmers in Gelanggang Village and 68 partner farmers in Sukadana Village. The PLS evaluation model consists of three parts, namely the evaluation of the measurement model (outer model) more specifically about the relationship of indicator blocks or question items to variables, the evaluation of 
structural models (Inner models) that specifically connect between latent variables and hypothesis testing. The PLS inner model is also called an inner relation which describes the relationship between latent variables based on the substance of theory. The equation model in this study according to the picture is:

$$
\begin{gathered}
\mathrm{Y} 1=\beta 1 \mathrm{X} 1+\beta 2 \mathrm{X} 2+\beta 3 \mathrm{X} 3+\beta 4 \mathrm{X} 4+\varepsilon 1 \\
\mathrm{Y} 2=\beta 6 \mathrm{X} 1+\beta 7 \mathrm{X} 2+\beta 8 \mathrm{X} 3+\beta 9 \mathrm{X} 4+\beta 10 \mathrm{Y} 1+\varepsilon 2
\end{gathered}
$$

Where: $\mathrm{X} 1=$ The intensity of the partnership; $\mathrm{X} 2=$ Entrepreneurial orientation; $\mathrm{X} 3=$ The role of government; $X 4$ = Social capital; $Y 1=$ Product competitiveness; $Y 2$ = Farmers Welfare; $\beta 1 \ldots . . . \beta 11=$ Path Coef; $\varepsilon 1$ and $\varepsilon 2=$ Inner residuals.

\section{RESULTS OF STUDY}

Convergent validity is measured based on the outer loading test criteria of each indicator. Outer loading values ranging from 0.654 to 0.982 indicate all indicators are declared valid and significant. The outer loading value of each indicator variable is presented as follows.

\begin{tabular}{|c|c|c|c|c|c|c|}
\hline Variable & Indicator & $\begin{array}{l}\text { Original } \\
\text { Sample (O) }\end{array}$ & $\begin{array}{l}\text { Sample } \\
\text { Mean (M) }\end{array}$ & $\begin{array}{l}\text { Standard } \\
\text { Deviation } \\
\text { (STDEV) }\end{array}$ & $\begin{array}{l}\text { T Statistics } \\
(|O / S T D E V|)\end{array}$ & $\begin{array}{l}P \\
\text { Values }\end{array}$ \\
\hline \multirow[t]{3}{*}{ Partnership Intensity (X1) } & $\begin{array}{l}\text { Availability of production } \\
\text { facilities (X11) }\end{array}$ & 0.885 & 0.770 & 0.346 & 2.562 & 0.011 \\
\hline & $\begin{array}{l}\text { Guidance and Coaching } \\
\text { (X12) }\end{array}$ & 0.879 & 0.770 & 0.283 & 3.102 & 0.002 \\
\hline & $\begin{array}{l}\text { Marketing of Production } \\
\text { Results (X13) }\end{array}$ & 0.701 & 0.581 & 0.334 & 2.101 & 0.036 \\
\hline Entrepreneurship & Use Value (X21) & 0.828 & 0.832 & 0.050 & 16.641 & 0.000 \\
\hline \multirow[t]{4}{*}{ Orientation (X2) } & Internal motivation (X22) & 0.798 & 0.795 & 0.063 & 12.753 & 0.000 \\
\hline & Risk (X23) & 0.842 & 0.835 & 0.063 & 13.360 & 0.000 \\
\hline & Profit Opportunities (X24) & 0.839 & 0.835 & 0.046 & 18.101 & 0.000 \\
\hline & Intuition (X25) & 0.654 & 0.640 & 0.134 & 4.871 & 0.000 \\
\hline \multirow[t]{3}{*}{$\begin{array}{l}\text { The Role of Government } \\
\text { (X3) }\end{array}$} & $\begin{array}{l}\text { Business Opportunities } \\
\text { (X31) }\end{array}$ & 0.974 & 0.974 & 0.013 & 73.395 & 0.000 \\
\hline & $\begin{array}{l}\text { Development / Productivity } \\
\text { (X32) }\end{array}$ & 0.982 & 0.983 & 0.005 & 202.040 & 0.000 \\
\hline & Protection (X33) & 0.965 & 0.963 & 0.019 & 51.583 & 0.000 \\
\hline \multirow[t]{3}{*}{ Social Capital (X4) } & Norm (X41) & 0.856 & 0.818 & 0.175 & 4.885 & 0.000 \\
\hline & Network (X42) & 0.896 & 0.858 & 0.123 & 7.316 & 0.000 \\
\hline & Trust (X43) & 0.818 & 0.803 & 0.130 & 6.296 & 0.000 \\
\hline \multirow[t]{7}{*}{$\begin{array}{l}\text { Product Competitiveness } \\
\text { (Y1) }\end{array}$} & $\begin{array}{l}\text { Production Processing } \\
(\text { Y11) }\end{array}$ & 0.924 & 0.924 & 0.022 & 41.236 & 0.000 \\
\hline & Internal conditions (Y12) & 0.906 & 0.905 & 0.033 & 27.379 & 0.000 \\
\hline & $\begin{array}{l}\text { In accordance with quality } \\
\text { standards (Y13) }\end{array}$ & 0.882 & 0.881 & 0.037 & 23.650 & 0.000 \\
\hline & $\begin{array}{l}\text { Following the program } \\
(\mathrm{Y} 14)\end{array}$ & 0.780 & 0.775 & 0.080 & 9.732 & 0.000 \\
\hline & $\begin{array}{l}\text { Find alternative markets } \\
\text { (Y15) }\end{array}$ & 0.699 & 0.697 & 0.080 & 9.732 & 0.000 \\
\hline & $\begin{array}{l}\text { Always production quality } \\
\text { oriented (Y16) }\end{array}$ & 0.886 & 0.883 & 0.042 & 20.909 & 0.000 \\
\hline & $\begin{array}{l}\text { Existence of farmer loyalty } \\
(\mathrm{Y} 17)\end{array}$ & 0.786 & 0.782 & 0.073 & 10.793 & 0.000 \\
\hline \multirow[t]{4}{*}{ Farmers' Welfare (Y2) } & Increased Revenue (Y21) & 0.864 & 0.861 & 0.033 & 26.343 & 0.000 \\
\hline & Family Education (Y22) & 0.911 & 0.909 & 0.022 & 40.674 & 0.000 \\
\hline & Family Health (Y23) & 0.785 & 0.777 & 0.074 & 10.668 & 0.000 \\
\hline & $\begin{array}{l}\text { Social and spiritual life } \\
\text { (Y24) }\end{array}$ & 0.835 & 0.827 & 0.052 & 16.125 & 0.000 \\
\hline
\end{tabular}

Table 2 - The Outer Louding Coefficient Value of Each Indicator of the Construction Variable

Good discriminant validity is the Average Variance Extracted (AVE) square root for each construct greater than 0.50 . The root value of AVE for each dimension ranges from 0.50 to 0.70 , indicating the results of discriminant testing in accordance with the required AVE value is greater than 0.50 (Lathan and Ghozali, 2012: 78-79). Based on the AVE value of the reflective variable fulfills the convergence validity requirements. 
Table 3 - Discriminant Validity Checks

\begin{tabular}{ll}
\hline Discriminant Validity Checks & \\
\hline Variable & AVE \\
\hline Partnership Intensity (X1) & 0.683 \\
Entrepreneurship Orientation (X2) & 0.633 \\
The Role of Government (X3) & 0.949 \\
Social Capital (X4) & 0.735 \\
Product Competitiveness (Y1) & 0.708 \\
Farmers' Welfare (Y2) & 0.722
\end{tabular}

Source: Data processed, 2019.

Composite reliability and Cronbach alpha is a measure of reliability between the indicator blocks in the research model. The composite reliability and Cronbach alpha values meet the reliable criteria, each with a value of $>0.70$, which shows all indicators that form dimensions of partnership intensity construction, entrepreneurial orientation, the role of government, social capital, product competitiveness and welfare are valid and reliable. The composite reliability and cronbach alphac values are presented as follows.

Table 4 - Cronbach's Alpha Check and Composite Reliability

\begin{tabular}{lll}
\hline Cronbach's Alpha Check and Composite Reliability & & \\
\hline Variable & Cronbach's Alpha & Composite Reliability \\
\hline Partnership Intensity (X1) & 0.764 & 0.865 \\
Entrepreneurship Orientation (X2) & 0.853 & 0.895 \\
The Role of Government (X3) & 0.973 & 0.982 \\
Social Capital (X4) & 0.819 & 0.893 \\
Product Competitiveness (Y1) & 0.930 & 0.944 \\
Farmers' Welfare (Y2) & 0.871 & 0.912 \\
\hline
\end{tabular}

Source: Data processed, 2019.

Based on Table 4 shows the Cronbach's Alpha coefficient greater than 0.50 indicates that all indicators are reliable and the composite reliability coefficient is greater than 0.50 then all indicators are reliable. So that the indicator is able to reliably collect the data needed in research with the lowest Cronbach's Alpha value of 0.764 and the highest of 0.973.

Evaluation of structural models (Structural Model / Inner Model) is a measurement to evaluate the level of accuracy of the model in the overall research, which is formed through several variables along with the indicators. In evaluating this structural model, it will be carried out through several approaches in PLS.3, the criteria used are R Square, F Square, and $Q$ Square predictive prelevance.

Nilai $R$ Square menunjukkan bahwa setiap variabel laten endogen sebagai kekuatan prediksi dari model struktural. Perubahan nilai R Square dapat digunakan untuk menjelaskan pengaruh yang substantive. Nilai $R$ Square 0,75 bahwa model kuat, 0,50 moderat, and 0,25 lemah (Latan and Ghozali, 2012;82). Nilai R Square masing-masing variabel di atas 0,50 menunjukkan model kuat. Hasil nilai R Square sebagai berikut,

Table 5 - R Square Coef.

\begin{tabular}{lll}
\hline Variable & R square & Criteria \\
\hline Product Competitiveness & 0.266 & Moderat \\
Farmer Welfare & 0.583 & Moderat \\
\hline
\end{tabular}

Source: Data processed, 2019. 
The R-square value of the product competitiveness variable is 0.266 meaning that 26.6 percent of product competitiveness is influenced by the variables of partnership intensity, entrepreneurial orientation, the role of government and social capital, while the remaining 73.4 percent is influenced by other variables outside the research model. Furthermore RSquare farmers 'welfare is 0.583 meaning that 58.3 percent of farmers' welfare is influenced by the variables of production competitiveness, partnership intensity, entrepreneurial orientation, the role of government and social capital, while the remaining 41.7 percent is influenced by other variables outside the research model.

Furthermore, to see the effect of exogenous latent constructs when there are or none on their endogenous variables, an effect size (f2) evaluation is used. Table 5.12 shows the effect size values for each relationship. Cohen (1998) divides effect size based on three criteria, namely 0.02-0.14 (small), 0.15-0.35 (medium), and>0.35 (large).

Table 6 - $f$ Square Coef.

\begin{tabular}{lll}
\hline Variable & f Square & Effect Category \\
Partnership Intensity $\rightarrow$ Product Competitiveness $(\mathrm{X} 1 \rightarrow \mathrm{Y} 1)$ & 0.069 & Small \\
Partnership Intensity $\rightarrow$ Farmer Welfare & 0.000 & Nothing \\
$(\mathrm{X} 1 \rightarrow \mathrm{Y} 2)$ & 0.241 & Average \\
Entrepreneurial orientation $\rightarrow$ Product Competitiveness & 0.103 & Small \\
$(\mathrm{X} 2 \rightarrow \mathrm{Y} 1)$ & 0.003 & Very small \\
Entrepreneurial Orientation $\rightarrow$ Farmer Welfare & 0.049 & Small \\
$(\mathrm{X} 2 \rightarrow \mathrm{Y} 2)$ & 0.005 & Very small \\
The Role of Government $\rightarrow$ Product Competitiveness & 0.025 & Small \\
$(\mathrm{X} 3 \rightarrow \mathrm{Y} 1)$ & 0.538 & Big \\
\hline
\end{tabular}

Source: Data processed, 2019.

Based on Table 6 clearly shows that based on the results of the calculation of the effect size on the effect of the intensity of the partnership on product competitiveness is small. Furthermore, the effect size calculation of the effect of the intensity of the partnership on the welfare of farmers is absent. In calculating the effect size the effect of entrepreneurial orientation on product competitiveness is moderate. In the calculation of the effect size the effect of entrepreneurial orientation on the welfare of farmers is small. In calculating the effect size the effect of the government's role on product competitiveness is very small. In calculating the effect size the effect of the government's role on the welfare of farmers is small. In the calculation of the effect size the effect of social capital on product competitiveness is very small. In the calculation of the effect size the effect of social capital on the welfare of farmers is small. In the calculation of the effect size the effect of product competitiveness on farmers' welfare is large.

The structural model is evaluated by observing the predictive relevance Q2 of the model that measures how well the observational value is generated by the model. Q2 is based on the coefficient of determination of all dependent variables. The quantity Q2 has a value with a range of $0<\mathrm{Q} 2<1$, the closer the value of one means the better the model. Q2 or Stone Geiser Q-Square test, namely:

Table 7 - Goodness of Fit Evaluation Result

\begin{tabular}{lll}
\hline Model & Dependent Variable & R-square \\
1 & Product competitiveness $(\mathrm{Y} 1)$ & 0.266 \\
2 & Farmer welfare $(\mathrm{Y} 2)$ & 0.583 \\
Calculation: $\mathrm{Q}^{2}=1-\left[\left(1-\mathrm{R}_{1}{ }^{2}\right)\left(1-\mathrm{R}_{2}{ }^{2}\right)\right]=0.693$ & \\
\hline
\end{tabular}

Q2 calculation results of 0.693 so that it can be said to have a high predictive prevelance, so the resulting model is feasible to use to predict. A figure of 0.693 can be interpreted that 69.3 percent variation in farmers' welfare can be explained by variation, partnership intensity, entrepreneurial orientation, the role of government, social capital and product competitiveness, while the remaining 30.7 percent is explained by variables outside 
the model. The results of the study indicate that the variables used to explain the welfare of partner farmers in virginia tobacco farming in East Lombok Regency. The relationship between variables tested in this study is the relationship between exogenous variables to endogenous variables, namely the relationship between variables, intensity of partnerships, entrepreneurial orientation, the role of government and social capital to product competitiveness and farmers' welfare. In this study also uses the mediating variable competitiveness of products on the welfare of farmers. The results of the path analysis between variables by displaying the t-value as follows;

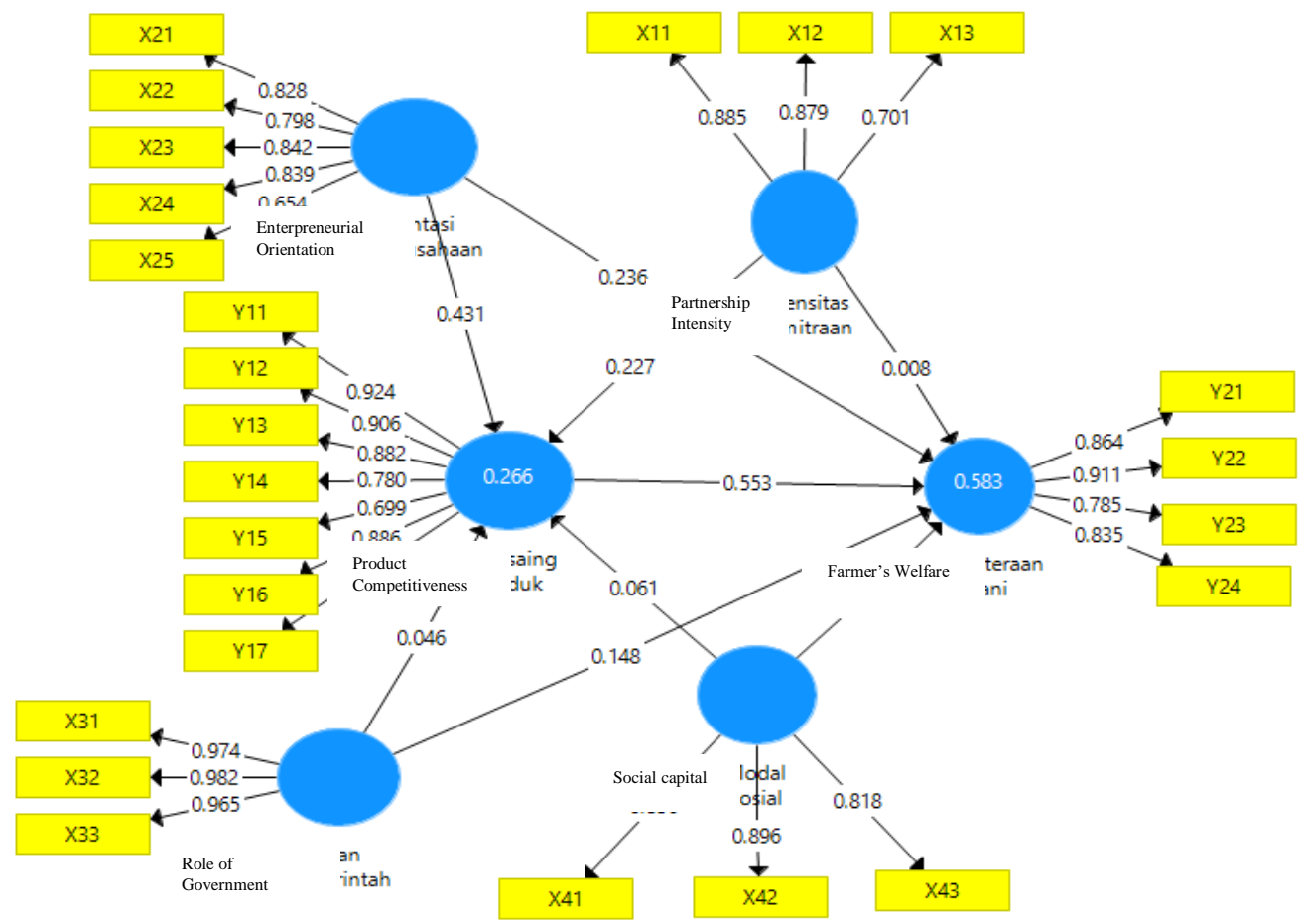

Figure 1 - Test Results of Research Models with SEM-PLS

There are nine direct relationships in this study to determine the direction of their influence seen from the original sample values, while to prove this direct relationship has a significant effect or is not indicated by the $P$ value.

Table 8 - Coefficient of Influence Between Research Variables

\begin{tabular}{|c|c|c|c|c|c|}
\hline Variable & $\begin{array}{c}\text { Original } \\
\text { Sample }(O)\end{array}$ & $\begin{array}{c}\text { Sample } \\
\text { Mean (M) }\end{array}$ & $\begin{array}{l}\text { Standard } \\
\text { Deviation } \\
\text { (STDEV) }\end{array}$ & $\begin{array}{c}\text { T Statistics } \\
(|O / S T D E V|)\end{array}$ & $\begin{array}{c}P \\
\text { Values }\end{array}$ \\
\hline $\begin{array}{l}\text { Partnership Intensity } \rightarrow \text { Product } \\
\text { Competitiveness }(\mathrm{X} 1 \rightarrow \mathrm{Y} 1)\end{array}$ & 0.227 & 0.172 & 0.234 & 0.973 & 0.331 \\
\hline $\begin{array}{l}\text { Partnership Intensity } \rightarrow \text { Farmer Welfare } \\
\qquad(\mathrm{X} 1 \rightarrow \mathrm{Y} 2)\end{array}$ & 0.008 & 0.003 & 0.131 & 0.065 & 0.948 \\
\hline $\begin{array}{l}\text { Entrepreneurial orientation } \rightarrow \text { Product } \\
\quad \text { Competitiveness }(\mathrm{X} 2 \rightarrow \mathrm{Y} 1)\end{array}$ & 0.431 & 0.443 & 0.120 & 3.603 & $0.000^{*}$ \\
\hline $\begin{array}{l}\text { Entrepreneurship Orientation } \rightarrow \text { Farmer } \\
\text { Welfare }(\mathrm{X} 2 \rightarrow \mathrm{Y} 2)\end{array}$ & 0.236 & 0.262 & 0.088 & 2.671 & $0.008^{*}$ \\
\hline $\begin{array}{c}\text { The Role of Government } \rightarrow \text { Product } \\
\text { Competitiveness }(\mathrm{X} 3 \rightarrow \mathrm{Y} 1)\end{array}$ & 0.046 & 0.022 & 0.083 & 0.552 & 0.581 \\
\hline $\begin{array}{c}\text { The Role of Government } \rightarrow \text { Farmers' } \\
\text { Welfare }(\mathrm{X} 3 \rightarrow \mathrm{Y} 2)\end{array}$ & 0.148 & 0.147 & 0.068 & 2.160 & $0.031^{*}$ \\
\hline $\begin{array}{l}\text { Social Capital } \rightarrow \text { Product } \\
\text { Competitiveness }\end{array}$ & 0.105 & 0.112 & 0.077 & 1.366 & 0.172 \\
\hline $\begin{array}{c}(\mathrm{X} 4 \rightarrow \mathrm{y} 1) \\
\text { Social Capital } \rightarrow \text { Farmer Welfare }\end{array}$ & $\begin{array}{l}0.061 \\
0.553\end{array}$ & $\begin{array}{l}0.092 \\
0.516\end{array}$ & $\begin{array}{l}0.122 \\
0.105\end{array}$ & $\begin{array}{l}0.500 \\
5.246\end{array}$ & $\begin{array}{l}0.617 \\
0.000^{*}\end{array}$ \\
\hline
\end{tabular}

Based on Table 8, it can be explained that all direct effects between the research variables are positive from nine significant relationships between the four variables, namely 
entrepreneurial orientation towards product competitiveness, entrepreneurial orientation towards farmers' welfare, the role of government towards farmers' welfare and product competitiveness towards farmers' welfare. While the insignificant direct relationships numbered five, namely the intensity of partnerships on product competitiveness, intensity of partnerships on farmers 'welfare, the role of the government on competitiveness, social capital on product competitiveness and social capital on farmers' welfare. Examination of this mediation model is carried out as an effort to provide information on the level of intervention of the mediating variable, whether full mediation (full mediation) or partial mediation (partial mediation).

Table 9 - Indirect Direct Effect and Total Influence between Variables

\begin{tabular}{|c|c|c|c|}
\hline Path Variable & Direct Effect & Indirect Effect & Total Effect \\
\hline Partnership intensity $\rightarrow$ Farmer welfare & 0.008 & $\begin{array}{l}0.0044 \\
\left(0.008^{*} 0.553\right)\end{array}$ & 0.0124 \\
\hline Entrepreneurship Orientation $\rightarrow$ Farmer welfare & 0.236 & $0.1305(0.236 * 0.553)$ & 0.3665 \\
\hline The Role of Government $\rightarrow$ Farmer's welfare & 0.148 & $\begin{array}{l}0.0818 \\
\left(0.148^{\star} 0.553\right)\end{array}$ & 0.2298 \\
\hline Social capital $\rightarrow$ Farmer welfare & 0.105 & $\begin{array}{l}0.0580 \\
\left(0.105^{\star} 0.553\right)\end{array}$ & 0.163 \\
\hline
\end{tabular}

The results of testing the hypothesis as a whole and the coefficient value of each path (direct and indirect effects), then a path diagram is arranged, as shown in Figure 2.

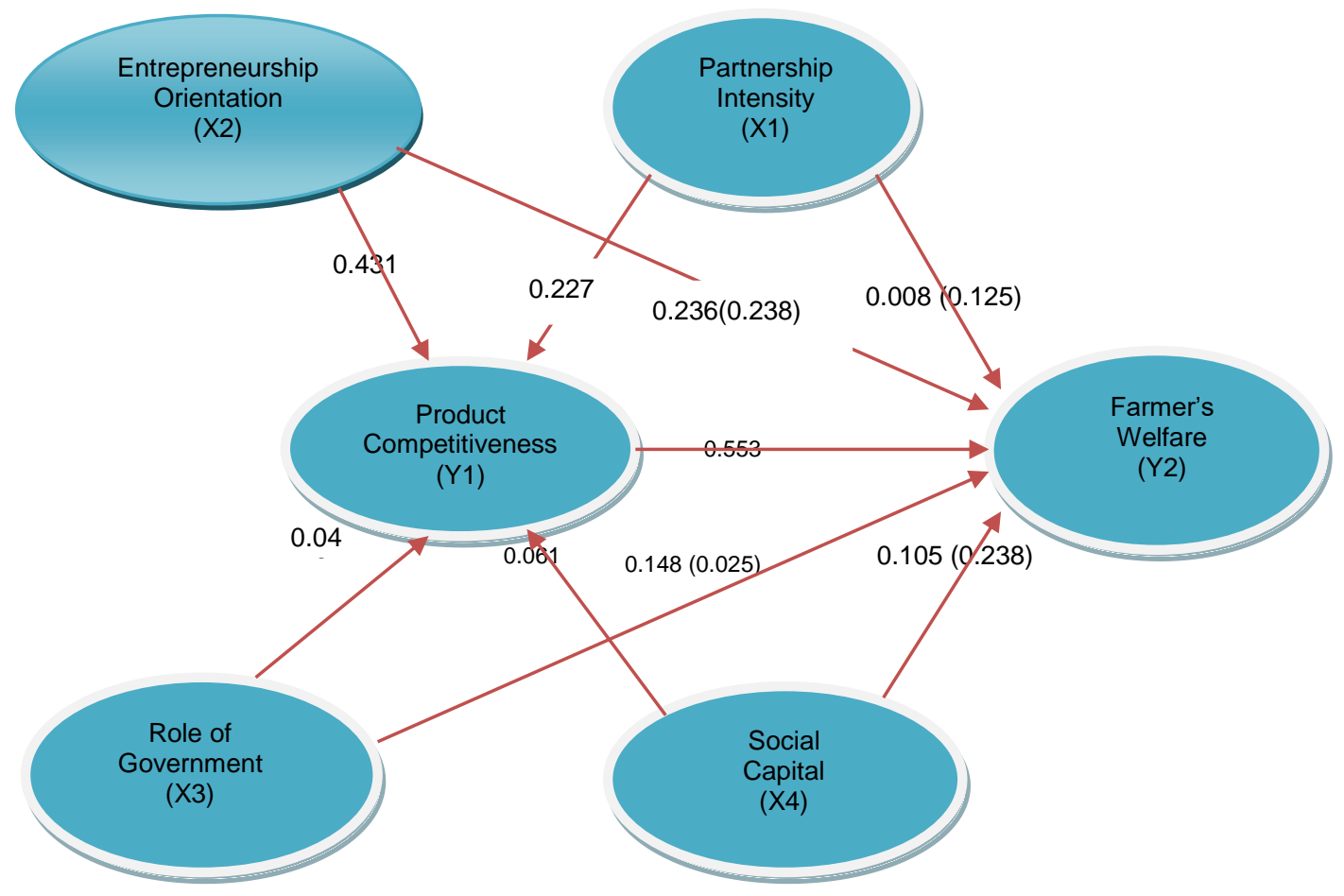

Figure 2 - Direct and Indirect Effects

Based on the results of the overall hypothesis testing, it can be seen the significance of each path or path that illustrates the model of the results of this study (Figure 2) By considering the model of research results, it can be described the research findings as follows:

- Pathway from partnership intensity $\rightarrow$ Product competitiveness $\rightarrow$ farmer welfare. This finding means that the intensity of the partnership is not an important determinant in the competitiveness of products to improve or improve the welfare of farmers. It is proven that product competitiveness does not partially mediate the effect of partnership intensity on farmers' welfare. This finding shows that the welfare of 
farmers is not supported by the intensity of partnerships through increased product competitiveness;

- Pathway from entrepreneurial orientation $\rightarrow$ product competitiveness $\rightarrow$ farmers' welfare. These results indicate that, entrepreneurial orientation is an important determinant in product competitiveness to achieve improvement in farmers' welfare. It is also evident that the competitiveness of products partially mitigates the effect of entrepreneurial orientation on improving farmers' welfare. These findings indicate that, the better the entrepreneurial orientation, the better the welfare of farmers through product competitiveness;

- Pathways from the role of government $\rightarrow$ Product competitiveness $\rightarrow$ Farmer welfare. This finding means that the role of government is not an important determinant of product competitiveness towards improving or improving farmers' welfare. It is proven that the competitiveness of products does not partially mediate the effect of the government's role on the welfare of farmers. This finding shows that the welfare of farmers is not supported by the government's role through increasing product competitiveness;

- Pathways from social capital $\rightarrow$ Product competitiveness $\rightarrow$ Farmer welfare. This finding gives the sense that, social capital is not as an important determinant in product competitiveness to improve or improve the welfare of farmers. It is proven that product competitiveness does not partially mediate the effect of social capital on farmers' welfare. This finding shows that farmers' welfare is not supported by social capital through increasing product competitiveness.

Statistical test results of the relationship between variables can be stated that the value of the coefficient of the relationship between the intensity of partnerships with the competitiveness of a product of 0.227 is positive and not significant at a significant level $\alpha=$ 0.05 . This means that the relationship intensity of partnerships with product competitiveness has a direct effect, namely the higher the intensity of partnerships, the competitiveness of products increases but is not significant. Based on these results, the first hypothesis $(\mathrm{H} 1)$ proposed is not proven or cannot be accepted in other words the hypothesis ( $\mathrm{HO})$ is accepted.

Statistical test results of the relationship between variables can be stated that the coefficient of the relationship between the intensity of partnerships with the welfare of farmers amounting to 0.008 is positive and not significant at a significant level $\alpha=0.05$. This means that the relationship intensity of partnerships with farmers' welfare has a direct effect, namely the higher the intensity of partnerships, the welfare of farmers is increasing but not significant. Based on these results, the first hypothesis $(\mathrm{H} 2)$ proposed is not proven or cannot be accepted in other words the hypothesis $(\mathrm{HO})$ is accepted.

Statistical test results of the relationship between variables can be stated that the value of the correlation coefficient between entrepreneurial orientation with product competitiveness of 0.431 is positive and significant at a significant level $\alpha=0.05$. This means that the relationship intensity of partnerships with farmers' welfare has a direct effect, namely the higher entrepreneurial orientation, the product competitiveness is increasing and significant. Based on these results, the first hypothesis $(\mathrm{H} 3)$ proposed is proven or can be accepted in other words the hypothesis $(\mathrm{H} 0)$ is rejected.

Statistical test results of the relationship between variables can be stated that the coefficient of the relationship between entrepreneurial orientation with the welfare of farmers of 0.236 is positive and significant at a significant level $\alpha=0.05$. This means that the relationship between entrepreneurship orientation with the welfare of farmers has a direct effect, namely the higher the entrepreneurial orientation, the welfare of farmers is increasing and significant. Based on these results, the first hypothesis $(\mathrm{H} 4)$ presented is proven or can be accepted in other words the hypothesis $(\mathrm{H} 0)$ is rejected. Statistical test results of the relationship between variables can be stated that the coefficient of the relationship between the role of government with product competitiveness of 0.046 is positive and not significant at a significant level $\alpha=0.05$. This means that the relationship between the role of government and the welfare of farmers has a direct effect, namely the higher the role of the government, 
the product competitiveness is increasing and insignificant. Based on these results, the first hypothesis (H5) proposed is not proven or cannot be accepted in other words the hypothesis $(\mathrm{H} 0)$ is accepted.

Statistical test results of the relationship between variables can be stated that the coefficient of the relationship between the role of the government and the welfare of farmers amounted to 0.148 positive and significant at a significant level $\alpha=0.05$. This means that the relationship between the role of government and the welfare of farmers has a direct effect, namely the higher the role of government, the welfare of farmers is increasing and significant. Based on these results, the first hypothesis (H6) proposed is proven or can be accepted in other words the hypothesis $(\mathrm{HO})$ is rejected. Statistical test results of the relationship between variables can be stated that the coefficient of the relationship between social capital and product competitiveness of 0.061 is positive and not significant at a significant level $\alpha=0.05$. This means that the relationship of social capital with product competitiveness has a direct effect, ie the stronger social capital, the product competitiveness increases. This condition shows that social capital has a positive and not significant effect on product competitiveness. Based on these results, the hypothesis seven $(\mathrm{H} 7)$ proposed is not proven or in other words the hypothesis $(\mathrm{H} 0)$ is accepted.

Statistical test results of the relationship between variables can be stated that the coefficient of the relationship between social capital and farmer welfare of 0.105 is positive and not significant at a significant level $\alpha=0.05$. This means that the relationship of social capital with the welfare of farmers has a direct influence, namely the stronger social capital, the welfare of farmers increases and is not significant. Based on these results, the eight hypothesis $(\mathrm{H} 8)$ proposed is not proven or in other words the hypothesis $(\mathrm{H} 0)$ is accepted. Statistical test results of the relationship between variables can be stated that the coefficient of the relationship between product competitiveness with the welfare of farmers is 0.553 positive and significant at a significant level $\alpha=0.05$. This means that the relationship of product competitiveness with the welfare of farmers has a direct effect, namely the higher the competitiveness of products, the welfare of farmers increases. This condition shows that product competitiveness has a positive and significant effect on welfare. Based on these results, the hypothesis nine $(\mathrm{H} 9)$ presented is proven or in other words the hypothesis $(\mathrm{H} 0)$ is rejected.

Statistical test results of the indirect relationship between variables can be stated that the value of the coefficient of the relationship between the intensity of partnerships to the welfare of farmers through product competitiveness of 0.126 is positive and not significant at a significant level $\alpha=0.05$. This means that the relationship of partnership intensity with farmers' welfare through product competitiveness does not have a direct and insignificant influence. Based on these results, the hypothesis ten $(\mathrm{H} 10)$ that was put forward was not proven or unacceptable in other words the hypothesis $(\mathrm{H} 0)$ that was accepted was rejected. The results of the statistical test of the indirect relationship between variables can be stated that the coefficient of the relationship between entrepreneurial orientation to the welfare of farmers through product competitiveness of 0.238 is positive and significant at a significant level $\alpha=0.05$. This means that the relationship between entrepreneurship orientation with the welfare of farmers through product competitiveness has a direct and significant influence. Based on these results, the eleven hypothesis $(\mathrm{H} 11)$ presented is proven or acceptable in other words the hypothesis $(\mathrm{H} 0)$ is rejected. The results of the statistical test of the indirect relationship between variables can be stated that the coefficient of the relationship between the role of the government on the welfare of farmers through product competitiveness of 0.025 is positive and not significant at a significant level $\alpha=0.05$. This means that the relationship between the role of government and the welfare of farmers through product competitiveness does not have a direct and insignificant influence. Based on these results, the twelve hypothesis $(\mathrm{H} 12)$ that was put forward was not proven or could not be accepted in other words the hypothesis $(\mathrm{H} 0)$ was accepted. Statistical test results of the indirect relationship between variables can be stated that the coefficient of the relationship between social capital to the welfare of farmers through product competitiveness of 0.034 is positive and not significant at a significant level $\alpha=0.05$. This means that the relationship between 
social capital and welfare through product competitiveness does not have a direct and significant influence. Based on these results, thirteen hypotheses $(\mathrm{H} 13)$ that were put forward were not proven or unacceptable in other words the hypothesis $(\mathrm{H} 0)$ was accepted.

\section{DISCUSSION OF RESULTS}

The entrepreneurial orientation factor has a direct and significant effect on the competitiveness of virginia tobacco products in East Lombok Regency, West Nusa Tenggara Province. The patterns of thinking and behavior of partner farmers are changed by education and training so that farmers make plans, analyze costs and production revenues so they can generate profits. Partner farmers will produce virginia tobacco products in accordance with the quality standards set by the company. If quality standards are set by partner farmers, the tobacco products will be able to be marketed to the domestic and international market so that they have product competitiveness. The indicator used to measure the entrepreneurship orientation of use values by asking farmers to try to increase income from virginia tobacco farming.

Entrepreneurial orientation has positive and significant effect on the welfare of East Lombok tobacco farmers. This shows to change the behavior of partner farmers in managing their farming should be based on the principle of entrepreneurial orientation, so to improve the welfare of farmers can by intervening from the factor of entrepreneurial orientation. Traditional cropping patterns are carried out with adequate knowledge and technology, but there have been changes due to education and training by field counselors from partner companies to form partner farmers must be brave to face risks, be able to see profit opportunities, be able to generate profits, have a strong will in the development of farming and sensitive facing changes in the use of technology in the production process so that it can be efficient.

The results of this study indicate that the role of government has a positive and significant effect on the welfare of farmers. This shows that in an effort to improve the welfare of partner farmers, the presence of the government in carrying out supervision in the implementation of the partnership process runs with no parties being harmed or running in a mutually beneficial, mutually reinforcing and interdependent manner. It was found in the field of moral hazard that can be done by partner farmers themselves in the form of selling products to non-partner companies so that partner farmers avoid bills on their credit and also with the reason of getting a high price. Moral hazard can be carried out by partner companies in the form of not absorbing all virginia tobacco products. Partner farmers have reason to be over-production so that it has an impact on low prices which causes them not to get maximum profit or loss.

The competitiveness of Lombok virginia tobacco products directly affects the positive and significant direction of the welfare of farmers. This shows that improving the competitiveness of virginia tobacco products will be able to improve the welfare of farmers. Measuring the competitiveness of the products of partner farmers doing land management, maintenance and composting in accordance with field counseling with the aim of producing quality products according to company standards. Farmers always plant tobacco with attention to soil and weather nutrient conditions, fertilizer composition according to company instructions. Partner farmers always produce virginia tobacco products according to quality standards set by the company, always increasing network expansion to those who have a market. Partner farmers must develop creativity in order to improve product quality and partner farmers always expect the continuity of virginia tobacco farming in Lombok. Entrepreneurial orientation is more dominant towards product competitiveness compared to farmers' welfare. It is shown that entrepreneurial orientation towards the welfare of farmers through the competitiveness of positive and significant value products means that the relationship between entrepreneurship orientation and the welfare of farmers through product competitiveness has a direct and significant influence. Improving the welfare of Lombok Virginia tobacco partner farmers can be done by improving product competitiveness, because by making improvements to the product competitiveness, it can be an intermediary 
for entrepreneurial orientation variables to improve farmers' welfare. Seeing that farmers are trying to increase income from the Virginia tobacco farming Lombok, partner farmers have a strong, passionate desire to develop the Virginia tobacco business. Education and training to change the mindset and behavior of these partner farmers can be done to improve the welfare of farmers as reflected in the increase in income from virginia tobacco farming.

The intensity of the partnership is more dominant on the competitiveness of products compared to the welfare of farmers. The results of this study indicate that the indirect relationship between variables can be stated that the coefficient of the relationship between the intensity of partnerships to the welfare of farmers through product competitiveness is positive and not significant meaning the relationship of partnership intensity with the welfare of farmers through product competitiveness does not have a direct and significant influence. The role of government is more dominant on the welfare of farmers compared to product competitiveness. The indirect relationship between variables can be stated that the coefficient of the relationship between the role of the government on the welfare of farmers through the competitiveness of positive and insignificant values means the relationship between the role of the government and the welfare of farmers through product competitiveness does not have a direct and significant influence. The results of this study found that the influence of social capital was more dominant on the welfare of farmers compared to the product competitiveness. The indirect relationship between variables can be stated that the coefficient of the relationship between social capital to the welfare of farmers through product competitiveness is positive and not significant meaning the relationship between social capital and welfare through product competitiveness does not have a direct and significant effect.

\section{CONCLUSION}

Statistical test results of the relationship between variables can be stated that the relationship between the intensity of partnerships with product competitiveness has a direct effect that is the higher the intensity of partnerships, the competitiveness of products increases but is not significant. The relationship of partnership intensity with farmers 'welfare has a direct effect, namely the higher the intensity of the partnership, the farmers' welfare increases but not significantly. The relationship between entrepreneurship orientation and product competitiveness has a direct effect, namely the higher entrepreneurial orientation, the product competitiveness is increasing and significant. The relationship between entrepreneurship orientation and farmers 'welfare has a direct effect, the higher the entrepreneurial orientation, the farmers' welfare is increasing and significant. The relationship between the role of government and product competitiveness has a direct effect, namely the higher the role of government, the product competitiveness is increasing and not significant. The relationship between the role of government and the welfare of farmers has a direct effect, namely the higher the role of the government, the welfare of farmers is increasing and significant. The relationship of social capital with product competitiveness has a direct effect that is the stronger social capital, the product competitiveness is increasing. This condition shows that social capital has a positive and not significant effect on product competitiveness. The relationship of social capital with the welfare of farmers has a direct influence, namely the stronger social capital, the welfare of farmers is increasing and not significant.

The relationship of product competitiveness with the welfare of farmers has a direct effect, namely the higher the competitiveness of products, the welfare of farmers is increasing. This condition shows that product competitiveness has a positive and significant effect on welfare. The relationship of partnership intensity with farmers' welfare through product competitiveness has no direct and insignificant influence. The relationship between entrepreneurship orientation and farmers' welfare through product competitiveness has a direct and significant influence. The relationship between the government's role and the welfare of farmers through product competitiveness has no direct and insignificant influence. The relationship between social capital and welfare through product competitiveness has no direct and significant influence. 


\section{REFERENCES}

1. Arthur, B. da Silva, Carlos. 2005. The Growing Role of Contract Farming in Agri-food System Development: Drivers, Theory and Practice. Paper Prepared for The Asian Productivity Organization Meeting on "Sustainable Contract Farming for Increased Competitiveness", Colombo, Sri Lanka.

2. Bappenas, RI. 2008. Perencanaan Indonesia Jangka Menengah. Jakarta. Indonesia

3. Bolwig, S. Peter, Gibbon, \& Sam, Jones. 2009. The Economics of Smallholder Organic Contract Farming in Tropical Africa. Journal of World Development, Vol. 37, No. 6, pp. 1094-1098.

4. Bronsteen, J. Christopher, B. \& Jonathan S. M. 2009. Welfare As Happiness. The Georetown Law Journal. Vol. 98, pp.1583. Electronic Copy Available at: http://ssrn.com/abstract=1397843.

5. Capello, R. \& Faggian, A. 2005. Collective learning and relational capital in local innovation processes. Regional Studies 39(1): 75-87.

6. Chapra, M. Umer. 2001. The Future of Economics: An Islamic Perspective. The Islamic Foundation, UK. Amdiar Amir, dkk (penterjemah). 2001. Shari'ah economics and Banking Institute. Jakarta.

7. Dirlanudin. 2010. Perilaku Wirausaha and Keberdayaan Pengusaha Kecil Industri Agro: Kasus di Kabupaten Serang Provinsi Banten. (Disertasi). Sekolah Pascasarjana, Institut Pertanian Bogor. Bogor.

8. Douma, S. \& Hein, Schreuder. 1992. Economic Approach to organization. Pntice Hall International (UK) Ltd.

9. Glover, D. 1994. Contract Farming and Commercialization of Agriculture in Developing Countries, Agricultural Commercialization, Economic Development and Nutrition. Baltimore, M.D: Johns Hopkins University Press.

10. Grinols, Earl, L. 1994. Microeconomics. Houghton Mifflin Company. Boston. Toronto. Genewa, Illinois Palo Alto Princeton, New Jersey.

11. Halil. 2013. Pengaruh Kemitraan terhadap Efisiensi Tembakau Virginia di Pulau Lombok Nusa Tenggara Barat. (Disertasi). Sekolah Pascasarjana Institut Pertanian Bogor. Bogor

12. Hamidi. 2010. Penyimpangan Kontrak dalam Kemitraan Agribisnis Tembakau Virginia di Pulau Lombok Nusa Tenggara Barat. Agroteksos vol. 20 no. 1 Desember 2010.

13. Kotler, P. 1997. Marketing Management: Analysis, Planning, Implementation, and Control. New Jersey (US): Prentice-Hall, Inc.

14. . 2008. Principle of Marketing. New Jersey (US): 12th Edition. Pearson Prentice- Hall. Inc.

15. Kurniawan. 2016. Pengaruh harga tembakau internasional, jumlah produksi domistik and nilai tukar terhadap nilai ekspor tembakau Indonesia. Jurnal Administrasi Bisnis (JAB) Vol. 38 no. 2 September 2016.

16. Kumar, S. A., Poornima, S. C., Abraham, M. K \& Jayashree, L. 2003. Enterprenurship Development. New Delhi (IN): New Age International.

17. Mazzarol, Tim., Thierry Volery., Noelle, Doss, \& Vicki Thein. 1999. Factors Influencing Small Business Start-ups. International Journal of Enterpreneurial Behaviour \& Research, Vol.5 No.2, 48-63.

18. Malecki, E. J. 2012. Regional social capital: Why it matters. Regional Studies, 46 (8): 1023-1039.

19. Mawardi, J. M. 2007. Peranan Sosial Capital dalam Pemberdayaan Masyarakat. Komunitas Jurnal Pengembangan Masyarakat Islam, Volume 3 Nomor 2.

20. Nicholson, Walter. 2002. Mikroekonomi Intermediate and Aplikasinya. (IGN. Bayu Mahendra and Abdul Aziz, pentj). Jakarta: PT. Penerbit Erlangga.

21. Partomo, T. S. \& Soejoedono, R. 2002. Ekonomi Skala Kecil Atau Menengah and Koperasi. Ghalia Indonesia. Jakarta.

22. Prasticha. 2003. Analisi produksi and pendapatan usahatani padi GP3K (Gerakan Peningkatan Produksi Pangan Berbasis Korporasi) and Non GP3K (Studi kasus di dusun 
Sekar Putih, Desa Pandem, Kecamatan Junrejo, Kota Baru. (Tesis) Universitas Briwijaya, Malang.

23. Rahayu, W. 2011. Strategi pengembangan komoditas pertaniaan unggulan di Kecamatan Kalitidu Kabupaten Bojnegoro. SEPA. Vol. 7, no. 2, pp. 1227-134.

24. Rutten, R., Westlund, H. \& Boekema F. 2010. The spatial dimension of social capital. European Planning Studies, 18 (6): 863-871.

25. Serad, H.S.M. 2006. Usaha Kemitraan dalam agribisnis tembakau. Prosiding diskusi panel revitalisasi system agribisnis tembakau bahan baku rokok. Pusat Penelitian and pengembangan Perkebunan, Bogor. P. 13-17.

26. Sjamsuddin, Sjamsiar. 2006. Kepemerintahan and kemitraan. Malang: CV. Sofa Mandiri

27. Surachmad. 2002. Informasi pasar and prediksi tembakau Virginia di masa depan. Peper disampaikan dalam rapat kerja program intensifikasi tembakau Virginia di Mataram, Nusa Tenggara Barat.

28. Stiglitz, Josep E, Amartaya, Send \& Jean-Paul Fitoussi. 2011. Mengukur Kesejahteraan Mengapa Produk Domistik Bruto Bukan Tolak Ukur yang Tepat untuk menilai kemajuan. (Mutiara Arumsari and Fitri Bintang Timur, Penterjemah). Bintan: Marjin Kiri.

29. Wirasasmita, Y. 2011. Ekonomika Kewirausahaan. Buletin Manajemen Kewirausahaan. Edisi Maret 2011. Hal. 3-5. Fakultas Ekonomi. Universitas Padjajaran. Bandung. 